\title{
Kroniek
}

\section{Kroniek concentratiecontrole 2017}

\author{
Gurgen Hakopian en Rachel Wouda*
}

\section{Inleiding}

Deze kroniek beschrijft de belangrijkste ontwikkelingen op het gebied van concentratiecontrole in Nederland in 2017. Zoals gebruikelijk begint de kroniek met een overzicht van de belangrijkste cijfers, gevolgd door een overzicht van de belangrijkste veranderingen in de toepasselijke wet- en regelgeving. Vervolgens komen sancties en rechtspraak en besluiten van de ACM in de meldingsfase en vergunningsfase aan bod.

Mr. G.R. Hakopian is advocaat bij De Brauw Blackstone Westbroek in Brussel. Mr. R.S. Wouda is advocaat bij De Brauw Blackstone Westbroek in Amsterdam. De auteurs (en/of hun kantoorgenoten) zijn in een aantal van de besproken zaken betrokken als advocaat.

1. Het jaarverslag van de ACM voor 2017 is nog niet gepubliceerd. Dit overzicht bevat daarom voorlopige, nog niet door ACM gepubliceerde cijfers.
Tabel 1 De cijfers ${ }^{1}$

Meldingen van fusies, overnames en joint 102

ventures (concentraties)

Aantal gemelde fusies die niet meldings- 0

plichtig waren

Ingetrokken meldingen 1

Verleende ontheffingen 1

Besluiten ACM op meldingen van concen- 103

traties

Vergunningseisen ACM voor concentra- 1

ties

Vergunningsaanvragen 1

Ingetrokken vergunningsaanvragen 0

Besluiten ACM op vergunningsaanvraag 2

\section{Wetgeving, informele zienswijzen en ontheffingen}

In 2017 hebben zich voor wat betreft het Nederlandse concentratietoezicht geen relevante wetswijzigingen voorgedaan. Ook heeft de ACM geen informele zienswijzen afgegeven met betrekking tot de toepassing van het concentratietoezicht. Dat is spijtig vanuit het oogpunt van duidelijkheid over de toepassing van de regels van het concentratietoezicht, maar geruststellend als het geïnterpreteerd wordt als signaal dat die regels voldoende duidelijk zijn. Ten slotte heeft de ACM in 2017 één ontheffing verleend van de verplichting van artikel 34 
Mw om na de melding van een concentratie een wachtperiode van vier weken in acht te nemen.

\section{Sancties en rechtspraak}

De ACM heeft in 2017 geen boetes opgelegd voor overtreding van de standstill-verplichting of voor andere overtredingen van de regels van het concentratietoezicht. Wel heeft de Rechtbank Rotterdam twee uitspraken gedaan, die beide goed hebben uitgepakt voor de ACM.

Lottovate en Stichting Speel Verantwoord/ACM Op 7 december 2015 heeft de ACM een vergunning verleend voor de fusie tussen Stichting Exploitatie Nederlandse Staatsloterij (hierna: de Staatsloterij) en Stichting Nationale Sporttotalisator (hierna: SNS) en De Lotto. Zowel het besluit van de ACM in de meldingsfase als het besluit in de vergunningsfase is in de kroniek van 2015 in dit tijdschrift uitgebreid besproken. ${ }^{2}$ Kort samengevat is de achtergrond van deze fusie de volgende. De Staatsloterij en de Lotto (die inmiddels zijn opgegaan in de Nederlandse Loterij) concurreerden met elkaar op de markt voor kansspelen, meer specifiek de markt voor loterijen en lottospelen. Zij droegen hun opbrengsten af aan respectievelijk de Staat en aan goede doelen. Op de Nederlandse markt zouden zij een gezamenlijk marktaandeel behalen van 52 procent. Er zou één concurrent overblijven, namelijk GDL. De ACM concludeerde na haar onderzoek in de vergunningsfase echter dat partijen slechts in beperkte mate concurrentiedruk op elkaar uitoefenden, omdat zij zich vooral richtten op het vergroten van omzet in hun eigen segment. Dat bleek ook uit het onderzoek dat partijen zelf hadden laten uitvoeren. Daarom heeft de ACM uiteindelijk opengelaten of de relevante productmarkt de markt voor loterijen en lottospelen was of nader gesegmenteerd moest worden. Verder achtte de ACM het onwaarschijnlijk dat de gefuseerde onderneming haar sterke positie zou kunnen inzetten op de toekomstige markt voor online kansspelen, zodanig dat die tot een significante belemmering van de mededinging zou kunnen leiden. Gezien het grote aantal buitenlandse partijen dat klaarstaat om die markt te betreden en ervaringen in het buitenland lag dat niet voor de hand.

Lottovate en Stichting Speel Verantwoord (hierna: SSV) hebben beroep ingesteld tegen de goedkeuring van de fusie bij de Rechtbank Rotterdam. Op 27 juli 2017 heeft de rechtbank de beroepen ongegrond verklaard. ${ }^{3}$

De rechtbank gaat eerst in op een beroep op niet-ontvankelijkheid door de ACM en de Nederlandse Loterij.

$\mathrm{Zij}$ betogen dat Lottovate geen belanghebbende is in de zin van artikel 1:2 Awb omdat Lottovate ten tijde van het instellen van het beroep niet op de markt voor loterijen en lottospelen actief was en dus geen concurrent

2. Besluit ACM 7 december 2015, zaak 15.0783.24 (SENS/SNS).

3. Rb. Rotterdam 27 juli 2017, ECLI:NL:RBROT:2017:5738 (Lottovate en Stichting Speel Verantwoord/ACM). was van de bij de fusie betrokken partijen. Ook zou Lottovate geen potentiële concurrent zijn, omdat destijds te veel onzekerheid bestond over de mogelijkheid van toetreding op de markt. SSV is volgens de ACM en de Nationale Loterij niet-ontvankelijk omdat de belangen die zij behartigt niet door het bestreden besluit worden geraakt. Uit de statuten van SSV blijkt namelijk dat zij tot doel heeft in een platform te voorzien voor gereguleerde online kansspelaanbieders waarbij hoge integriteitsstandaarden worden gewaarborgd en de maatschappelijke verantwoordelijkheid binnen de online kansspelindustrie wordt ondersteund. De rechtbank gaat hier niet in mee. Ten aanzien van Lottovate oordeelt de rechtbank dat het begrip 'potentiële concurrent' ruim moet worden uitgelegd. Lottovate was ten tijde van het bestreden besluit al bezig de markt te betreden. Dat blijkt onder andere uit een aanvraag voor een loterijvergunning en de procedures die zij daarover met de Kansspelautoriteit heeft gevoerd. Lottovate is daarmee belanghebbende. Ten anzien van SSV wijst de rechtbank erop dat SSV niet alleen het door partijen aangehaalde doel nastreeft, maar ook 'het verrichten van al hetgeen met het vorenstaande verband houdt of daartoe bevorderlijk kan zijn, alles in de ruimste zin van het woord'. SSV heeft zelf betoogd dat zij collectieve belangen behartigt van diverse bij haar aangesloten ondernemingen die op de markt opereren en die in Nederland vergunningaanvragen hebben gedaan. $\mathrm{Zij}$ is daarmee ook belanghebbende.

Voordat de rechtbank aan de inhoudelijke beoordeling toekomt, behandelt zij nog een beroep op het beginsel van equality of arms van met name SSV. De ACM heeft namelijk om beperkte kennisneming verzocht van bepaalde stukken en de rechter-commissaris heeft dat verzoek gerechtvaardigd geacht. De rechtbank oordeelt echter dat de procedure van artikel 8:29 Awb een met voldoende waarborgen omklede procedure is en dat het volgen van die procedure het recht op een eerlijke procesvoering niet in zijn essentie beperkt.

Dan de inhoud. Lottovate stelt ten eerste dat de ACM de relevante markt onjuist heeft afgebakend door uit te gaan van een markt van loterijen en lottospelen. Het besluit is volgens Lottovate bovendien innerlijk tegenstrijdig omdat de ACM ook heeft geconcludeerd dat de verschillende aanbieders op de markt slechts in beperkte mate concurrentiedruk op elkaar uitoefenen. SSV stelt daarnaast dat de ACM de marktafbakening niet open had mogen laten. De rechtbank volgt dit betoog niet en oordeelt, wijzend op de bestaande praktijk van de ACM en de Commissie, dat marktafbakening geen doel op zich is en er geen verplichting bestaat om een definitieve marktafbakening te hanteren. De ACM heeft volgens de rechtbank voldoende gemotiveerd waarom een definitieve marktafbakening niet nodig was. De ACM heeft onderzocht wat de gevolgen van de fusie zijn op de markt voor loterijen en lottospelen. Als de markt nauwer zou moeten worden afgebakend, en de door de Staatsloterij en de Lotto aangeboden diensten aparte productmarkten zouden vormen, zou er geen mededingingspro- 
bleem zijn (want immers geen overlap). Het besluit is daarmee ook niet tegenstrijdig.

Vervolgens betogen Lottovate en SSV dat de ACM om allerlei redenen onvoldoende en onzorgvuldig onderzoek gedaan naar de gevolgen van de concentratie op de markt. Lottovate betoogt dat de ACM ten onrechte heeft geconcludeerd dat het regulerend kader de concurrentie tussen partijen dempt. Naar het oordeel van de rechtbank heeft de ACM wel terecht gewezen op de wettelijke beperkingen. Dat de ACM in eerdere besluiten een iets ander standpunt innam is volgens de rechtbank niet relevant nu die besluiten sterk verouderd zijn. Verder meent zowel Lottovate als SSV dat de ACM de data die zij uit haar eigen regressieanalyse heeft gehaald gebrekkig en onvolledig heeft onderzocht en daaruit onjuiste conclusies heeft getrokken. Partijen hebben ter onderbouwing van dit standpunt een economisch rapport van E.CA Economics ingebracht, waaruit zou blijken dat de conclusies van de ACM niet door de feiten worden gedragen. Het gaat daarbij met name om de conclusie van de ACM dat het aantal verkochte loten van de verschillende loterijen en lottospelen van de ene partij slechts in beperkte mate verband houdt met variaties in concurrentieparameters van de andere partij of concurrent GDL. Volgens E.CA Economics zijn er aanwijzingen dat dit niet klopt, nu de verschillende loterijen consumenten verschillende opties bieden en met gebruik van productattributen en marketingcampagnes onderling concurreren om de loyaliteit van bestaande consumenten, om de incrementele uitgaven van bestaande consumenten en om nieuwe consumenten. De rechtbank veegt dit argument van tafel en baseert zich blijkens de uitspraak daarbij met name op wat een ACM-medewerker tijdens de zitting heeft verklaard. Deze medewerker heeft toegelicht dat sommige resultaten in de regressieanalyse van de ACM inderdaad bevestigden dat sprake is van enige competitieve interactie tussen enkele diensten van de Staatsloterij en de Lotto, maar dat deze interactie in sommige gevallen statistisch niet relevant is en dat het effect ervan voor het overige minimaal is. Bovendien heeft een externe deskundige van de ACM, prof. Fok van de Erasmus School of Economics, bevestigd dat de gekozen methodes in en de uitvoering van het onderzoek juist waren.

Vervolgens betogen Lottovate en SSV dat de ACM onvoldoende gemotiveerd heeft waarom zij de conclusies van het door haar ingeschakelde onderzoeksbureau Blauw, dat een conjunctanalyse had uitgevoerd, terzijde heeft geschoven. De ACM heeft echter uitgelegd dat de waarde van een dergelijke analyse minder groot is naarmate de door de respondenten aangegeven voorkeuren afwijken van de in de realiteit gemaakte keuzes, zonder dat daarvoor een goede verklaring is te vinden. Dat was hier het geval, wat betekent dat de ACM deze analyse buiten beschouwing mocht laten. Een interessant punt is dat Lottovate en SSV vervolgens stellen dat de ACM ten onrechte heeft geconcludeerd dat de interne documenten van partijen het beeld van beperkte concurrentie bevestigen. Afgaande op hun eerdere argument over equality of arms is immers aannemelijk dat Lottovate en
SSV deze stukken niet hebben gezien. De rechtbank heeft dat echter wel, en zij stelt vast dat in deze stukken vooral wordt geanalyseerd wat de samenstelling van de eigen klantenkring is en wat de invloed van uitkeringspercentages, hoogtes van de jackpot enzovoort is op de eigen verkoop. Analyses over de producten van andere aanbieders op de markt zijn er niet of nauwelijks. Ten slotte betogen Lottovate en SSV nog dat de ACM ten onrechte waarde heeft gehecht aan de opvatting van NSO, de brancheorganisatie voor de tabaksdetailhandel. NSO stelde dat partijen heel weinig met elkaar concurreren. De ACM heeft in het bestreden besluit gesteld dat dit aansluit bij haar bevindingen en de rechtbank kan zich vinden in deze conclusie.

De rechtbank verklaart de beroepen daarom ongegrond. SSV heeft hoger beroep ingesteld tegen de uitspraak.

\section{Mosadex e.a./ACM}

De tweede uitspraak van de Rechtbank Rotterdam betreft een vonnis van 7 september 2017 in het beroep van Mosadex C.V. en twee groepen zorgverzekeraars (hierna: Mosadex e.a.) tegen de goedkeuring door de ACM van de overname van Mediq Apotheken Nederland, Distrimed B.V. en Mediq Pharma Logistics door Brocacef Groep N.V. ${ }^{4}$ De besluiten van de ACM in deze zaak zijn in de kronieken van de afgelopen jaren uitgebreid besproken. De korte samenvatting van de casus is als volgt: de concentratie leidt tot mededingingsproblemen op de detailhandelsmarkt voor openbare apotheken en op de (landelijke) markt voor groothandelsleveringen aan ziekenhuizen. Als gevolg van de concentratie resteren er twee ongeveer even grote spelers, Brocacef en NFZ. Op de (landelijke) markt voor groothandelsleveringen aan ziekenhuizen heeft Brocacef na de voorgenomen concentratie een marktaandeel van 60-70 procent. Verder geldt dat de sterkte van de onderhandelingspositie van een apotheekketen niet alleen afhangt van het aantal apotheken dat deze vertegenwoordigt, maar ook van het aantal eigendomsapotheken dat onderdeel is van een keten. Er blijven twee landelijke ketens met eigendomsapotheken over. Als gevolg van de concentratie wordt Brocacef de sterkste speler op de markt. Zij vertegenwoordigt 594 apotheken, waarvan er 335 eigendomsapotheken zijn. De toename van lokale monopoliegebieden in het bezit van Brocacef is dusdanig groot dat Brocacef voor zorgverzekeraars een nog belangrijkere schakel in het contracteringsproces wordt. Het omslagpunt dat hierdoor wordt bereikt, kan ertoe leiden dat Brocacef gunstigere contractvoorwaarden voor de gehele keten weet te bewerkstelligen. De ACM achtte het aannemelijk dat deze toename in onderhandelingsmacht een prijsopdrijvend effect kon veroorzaken. De ACM concludeerde eveneens dat er onvoldoende afnemersmacht was om de toename in onderhandelingsmacht van Brocacef en dus de negatieve gevolgen voor patiënten te compenseren.

4. Rb. Rotterdam 7 september 2017, ECLI:NL:RBROT:2017:6833 (Mosadex e.a./ACM). 
De ACM was echter van oordeel dat de door de fusiepartijen aangeboden remedies voldoende zekerheid boden dat de geconstateerde mededingingsproblemen zonder twijfel en volledig worden weggenomen. Deze remedies zijn - kort samengevat - dat Brocacef na de overname 89 apotheken afstoot, met onder meer een groothandelsverbod aan deze apotheken voor de duur van twee jaar, en de groothandel Distrimed verkoopt aan Pluripharm.

Eisers (Mosadex e.a.) stellen dat de remedies de geconstateerde mededingingsproblemen niet wegnemen en bovendien geen structureel effect hebben. Zij stellen dat de ACM de zorginkoopmarkt te beperkt heeft onderzocht door ten onrechte de 'één-alternatiefgebieden' (de gebieden waarin voor Brocacef dan wel Mediq slechts één alternatief beschikbaar is) buiten beschouwing te laten. Verder is aangevoerd dat het groothandelsverbod van te korte duur is. Ook zijn uitsluitend enkele lokale ingrepen in de markt volgens Mosadex e.a. onvoldoende om een vliegwieleffect te voorkomen. Mosadex e.a. wijzen er in dit verband op dat Brocacef een groot aantal monopoliegebieden blijft behouden, zij als enige een landelijke keten van eigendomsapotheken heeft en de remedies relatief eenvoudig kunnen worden omzeild, bijvoorbeeld door het doen van overnames. Mosadex e.a. stellen dat Pluripharm niet beschikt over voldoende financiële middelen om duurzaam te kunnen concurreren met Brocacef.

Volgens de ACM zullen er in de 'één-alternatiefgebieden' als gevolg van de concentratie geen mededingingsproblemen ontstaan vanwege de afwezigheid van overlap tussen Brocacef en Mediq dan wel is het ontstaan van een machtspositie zeer onwaarschijnlijk vanwege de afwezigheid van dominantie (een marktaandeel van $<50$ procent). De ACM achtte een periode van twee jaar voldoende om de voormalige franchisenemers en partners in staat te stellen om bewust zelfstandige keuzes te maken over hun inkooprelatie. Mosadex e.a. hebben volgens de ACM niet aannemelijk kunnen maken dat een periode van twee jaar te kort zou zijn voor de voormalige franchisenemers en partnerapotheken om uit de invloedssfeer van Brocacef te raken. De ACM concludeerde daarnaast op basis van haar onderzoek dat Pluripharm over voldoende financiële middelen beschikt en voldoende ervaring en deskundigheid in huis heeft om Distrimed duurzaam voort te zetten.

De rechtbank is van mening dat de ACM voldoende aannemelijk heeft gemaakt dat als gevolg van de onderhavige concentratie, mede gelet op de opgelegde voorwaarden, de daadwerkelijke mededinging op de Nederlandse markt of een deel daarvan niet op significante wijze zou worden belemmerd. De beroepen zijn dan ook ongegrond.

De rechtbank volgt het betoog van de ACM en stelt dat de ACM in haar analyse voldoende aandacht heeft besteed aan de door eisers aangevoerde omstandigheden. Uit de analyse blijkt niet dat Brocacef door de toename van eigendomsapotheken zoveel onderhandelingsmacht krijgt, dat de zorgverzekeraars haar in het geheel niet meer kunnen disciplineren. Verder heeft de ACM in het bestreden besluit al gesteld dat Brocacef en Mediq vóór de concentratie met een gezamenlijk marktaandeel van 30 procent een sterke positie hebben op de nationale zorginkoopmarkt. Ter zitting is dit herhaald en is erop gewezen dat na implementatie van de remedies het marktaandeel van Brocacef 25 procent is. Dergelijke percentages zijn niet laag, maar hier wordt normaal gesproken geen mededingingsrechtelijk probleem in gezien.

De rechtbank is van oordeel dat de ACM terecht stelt dat het geconstateerde mededingingsprobleem door de remedies wordt weggenomen. Met de afstoting van eigendomsapotheken en het beëindigen van (bestaande) franchise- en partnerovereenkomsten is er geen overlap meer in (delen) van bepaalde gemeenten of daalt het gezamenlijk marktaandeel. Gelet op het beginsel van proportionaliteit kan de ACM niet meer van de fusiepartijen vragen dan nodig is.

Mosadex heeft tegen deze uitspraak hoger beroep ingesteld bij het College van Beroep voor het bedrijfsleven. De uitspraak kenmerkt zich, zoals wel meer uitspraken van de Rechtbank Rotterdam over concentratietoezicht, door een herhaling van de standpunten van de ACM en de constatering dat die standpunten zorgvuldig tot stand zijn gekomen, zonder veel eigen inzichten van de rechtbank daarover. Wij zijn dan ook benieuwd naar het oordeel van het $\mathrm{CBb}$.

\section{Meldingen en vergunningsaanvragen}

Ook in 2017 heeft de ACM verreweg de meeste concentraties in de meldingsfase goedgekeurd. Daarbij heeft de ACM de overgrote meerderheid van de besluiten zoals gewoonlijk verkort afgedaan: van de 103 besluiten van de ACM in de meldingsfase bevatten slechts 15 besluiten een inhoudelijke beoordeling. Het gebrek aan bruikbare precedenten voor de praktijk is in de kronieken van de voorgaande jaren steeds aangestipt. Datzelfde geldt voor de hoogte van de administratieve vergoeding van 17.450 euro die meldende partijen moeten betalen en de verhouding tussen die twee elementen. Wij blijven van mening dat een vergoeding aangepast aan de complexiteit van de beoordeling in een specifieke zaak meer recht zou doen aan de verhouding tussen de vergoeding en de arbeid die de ACM daadwerkelijk verricht.

\section{Meldingsfase}

In de paragrafen hieronder gaan wij in op vijf besluiten van de ACM in de meldingsfase. Een antal andere besluiten van de ACM in de meldingsfase die niet ver- 
kort zijn afgedaan laten wij in deze kroniek onbesproken. ${ }^{5}$

\section{Catharina Ziekenhuis/Anna Zorggroep}

Op 17 november 2017 heeft de ACM besloten dat een vergunning vereist is voor de fusie tussen het Catharina Ziekenhuis en de Sint Anna Zorggroep. ${ }^{6}$ De activiteiten van partijen overlappen op het gebied van klinische en niet-klinische algemene ziekenhuiszorg (basiszorg). De ACM is van mening dat het niet aannemelijk is dat als gevolg van de fusie de concurrentie beperkt zou worden op de markten voor verpleeghuiszorg, geriatrische revalidatiezorg, thuiszorg en topzorg en laat een verdere bespreking van deze markten daarom achterwege.

De ACM heeft voor de geografische afbakening zoals gebruikelijk gekeken naar de herkomst van patiënten. In het afgebakende gebied zijn drie ziekenhuizen actief: St. Anna, Catharina en een concurrent: het MMC.

Op de relevante markt hebben partijen samen een marktaandeel van 50-60 procent tegenover het MMC met 20-30 procent. Uit het onderzoek van de ACM volgt ook dat het Catharina de meeste concurrentiedruk ondervindt van het MMC en daarna van het St. Anna. Partijen hebben hierop aangevoerd dat er voor de meerderheid van de groep patiënten uit het afgebakende gebied meer alternatieven beschikbaar zijn: zo zou het eerste alternatief binnen dezelfde reistijd te bereiken zijn en zouden er vervolgens binnen 4 minuten extra reistijd nog twee alternatieven te bereiken zijn.

De ACM beoordeelt dat uit het onderzoek blijkt dat het

Catharina en het St. Anna belangrijke alternatieven voor elkaar zijn. De ACM erkent dat het St. Anna niet volledig dezelfde zorg kan aanbieden als het Catharina, maar vindt het aanbod voor het grootste deel van de aangeboden basiszorg wel degelijk een alternatief voor patiënten uit het werkgebied van het Catharina. Het St. Anna wordt door zorgverzekeraars gezien als het goedkopere alternatief. De ACM vindt het daarom aannemelijk dat zorgverzekeraars het St. Anna kunnen gebruiken als disciplineringsinstrument richting het Catharina en het MMC.

5. Dit zijn vrijwel allemaal besluiten die zien op de zorgsector. We zullen deze besluiten niet uitgebreid bespreken, aangezien ze alle geen specifieke bijzonderheden lijken te bevatten en er in deze en voorgaande kronieken al vele zorgfusies zijn besproken. Zo zijn er de volgende ziekenhuisfusies: besluit ACM 21 april 2017, zaak 16.1297.22 (Erasmus MC/Admiraal De Ruyter Ziekenhuis); besluit ACM 26 juni 2017, zaak 17.0459.22 (St. Antonius Ziekenhuis/Maartenskliniek Woerden); en een besluit over de markt voor GGZ van 9 februari 2017, zaak 16.0714.22 (Pluryn-Hoenderloo Groep/ Intermetzo). Ook laten we buiten beschouwing de volgende besluiten van de ACM op het gebied van ouderenzorg, huishoudelijke verzorging en revalidatiezorg: besluit ACM 24 maart 2017, zaak 17.0167.22 (Tzorg/Amstelring), besluit ACM 30 juni 2017, zaak 17.0420.22 (SHDH/Amie), besluit ACM 28 juli 2017, zaak 17.0517.22 (Stichting Surplus/Stichting Elisabeth/Stichting deBreedonk), besluit ACM 31 juli 2017, zaak 17.0473.22 (Stichting voor Regionale Zorgverlening/Stichting Ouderenzorg Kanaalzone) en besluit ACM 30 augustus 2017, zaak 17.0432.22 (Stichting Sophia/ Stichting Rijnlands Revalidatie Centrum). Ten slotte laten we een besluit in de markt voor medisch microbiologisch laboratoriumdiagnostiek buiten beschouwing: besluit ACM 8 juni 2017, zaak 17.0107.22 (Stichting Certe Medische Diagnostiek en Advies/Stichting Izore).

6. Besluit ACM 17 november 2017, zaak 17.0090.17 (Stichting Catharina Ziekenhuis/Stichting Sint Anna Zorggroep).
De ACM is van mening dat het voldoende aannemelijk is dat er door de voorgenomen fusie een verslechtering van de onderhandelingspositie voor zorgverzekeraars zal optreden. Er blijven niet genoeg alternatieven over voor de zorgverzekeraars en de positie van de partijen in de regio wordt dusdanig versterkt dat zorgverzekeraars niet meer om het fusieziekenhuis heen zullen kunnen. Opmerkelijk is dat de ACM tot die conclusie komt omdat de ACM het aannemelijk acht dat het St. Anna niet alleen in de onderhandelingen tussen verzekeraars en het Catharina een rol speelt, maar ook in de onderhandelingen met het MMC. Deze rol kan niet worden vervuld door de andere aanbieders die na de fusie op de relevante markt actief zijn. De ACM concludeert dat door het wegvallen van het St. Anna het aannemelijk wordt dat verzekeraars de ziekenhuizen minder goed zullen kunnen disciplineren. Dit zal niet alleen effect hebben op de afhankelijkheid van de zorgverzekeraars van de gefuseerde partij, maar ook van het MMC. De ACM lijkt hiermee een risico van gecoördineerde effecten te suggereren, zonder dat expliciet zo te stellen. Voor zover wij weten is het de eerste keer dat een dergelijke benadelingstheorie wordt geponeerd in de context van een ziekenhuisfusie. De ACM is daarom van mening dat een vergunning vereist is.

\section{Shanks/Van Gansewinkel}

Op 14 februari heeft de ACM goedkeuring verleend voor de concentratie tussen Shanks en Van Gansewinkel. $^{7}$ De activiteiten van partijen overlappen op het gebied van het inzamelen, sorteren en verwerken van gevaarlijk en niet-gevaarlijk afval en de levering van grondstoffen verkregen uit het recycleproces.

De activiteiten van afvalbedrijven kunnen worden onderscheiden naar het soort afval en naar de fase in de keten van afvalbeheer. Onder niet-gevaarlijk afval valt huishoudelijk afval, bedrijfsafval (commercieel en industrieel) en bouw- en sloopafval. Gevaarlijk afval is afval dat zowel bij de inzameling als bij de verwerking aan eisen moet voldoen op het gebied van brandveiligheid, milieu en volksgezondheid. Om dit soort afval te kunnen verzamelen en verwerken is een speciale opleiding voor chauffeurs nodig en zijn vergunningen vereist.

Op drie van de markten waar de activiteiten van partijen overlappen, namelijk de markt voor zuivering van bedrijfsafval, de markt voor industriële reiniging en de markt voor recycling van verpakkingsglas, ziet de ACM geen mededingingsproblemen. Op de markt voor zuivering van bedrijfsafvalwater bedienen Shanks en Van Gansewinkel verschillende typen opdrachtgevers en zijn zij dan ook niet elkaar naaste concurrenten. Bovendien is sprake van disciplinering vanuit klanten die zelf hun bedrijfsafval zuiveren. Gelet op de benodigde apparatuur, kennis, reinigingsmethoden en investeringen ziet de ACM de markt van industriële reiniging als aparte markt. Hoewel de partijen samen een marktaandeel van 30-40 procent hebben, richten ze zich niet op dezelfde winkel). 
klanten en zijn daarom slechts incidenteel elkaars directe concurrenten bij aanbestedingen. Op de markt voor recycling van glas kan een onderscheid worden gemaakt tussen vlakglas en verpakkingsglas en Shanks is alleen actief op de markt voor het recyclen van het laatste. De markt is niet beperkt tot Nederland, wat ervoor zorgt dat er op de markt grote internationale concurrentiedruk is.

De resterende markten van niet-gevaarlijk bedrijfsafval, de inzameling en recycling van verpakt (klein) gevaarlijk afval en de inzameling en recycling van onverpakt (bulk) gevaarlijk afval heeft de ACM diepgaander onderzocht.

De ACM maakt bij de inzameling van het niet-gevaarlijk bedrijfsafval een onderscheid tussen commercieel afval enerzijds, dat in het algemeen bij ieder bedrijf ontstaat en bestaat uit onder meer papier, glas en restafval, en industrieel afval anderzijds, dat bestaat uit specifieke afvalstromen uit de maakindustrie. Niet alleen verschilt het type afval, maar ook de inzamelingsfrequentie en -hoeveelheid, het type containers en het type vrachtwagens verschillen.

Partijen gaan hiervoor uit van een landelijke markt en het marktonderzoek bevestigt dit. Grotere afvalbedrijven zijn landelijk actief en kleinere bedrijven kunnen hun activiteiten op een grotere geografische schaal samenbundelen. Als gevolg van de fusie zouden de partijen op de markt voor de inzameling van niet-gevaarlijk industrieel afval een zeer gering gezamenlijk marktaandeel hebben. Op de markt voor inzameling van nietgevaarlijk commercieel bedrijfsafval zouden ze een gezamenlijk marktaandeel van 30-40 procent hebben, maar uit onderzoek van de ACM blijkt dat partijen zich nauwelijks op dezelfde aanbestedingen inschrijven en dat klanten heel beperkt tussen de partijen overstappen.

De markt voor de inzameling van verpakt (klein) gevaarlijk afval behelst de inzameling van gevaarlijk afval dat door degene die het afval produceert al zo is verpakt dat het op relatief eenvoudige wijze vervoerd kan worden. Deze markt verschilt van de inzameling van onverpakt (bulk) gevaarlijk afval in inzamelingsmiddel, vereiste vergunningen en specifieke behandeling waardoor overstappen naar de inzameling van onverpakt (bulk) gevaarlijk afval niet eenvoudig is. De markt voor het inzamelen van verpakt (klein) gevaarlijk afval is een nationale markt, doordat partijen met één of enkele depots voor de inzameling actief kunnen zijn in heel Nederland. Partijen hebben als gevolg van de fusie een gezamenlijk marktaandeel van maximaal 40 procent. Er gaat concurrentiedruk uit van veel grote en kleine spelers, er is overcapaciteit op de markt en de ACM concludeert bovendien dat Shanks en Van Gansewinkel niet elkaars meest nabije concurrenten zijn. De ACM concludeert daarom dat er geen effect op de mededinging in deze markt zal zijn.

Daarnaast zijn beide partijen actief op de markt voor (bulk) gevaarlijk afval dat komt van scheepvaart, raffinaderijen en de chemische industrie. De markt is nationaal. In het verleden heeft de ACM geoordeeld dat er onderscheid moet worden gemaakt naar de herkomst van de bulk en specifiek voor land- en scheepsafvalstro- men aangezien er voorheen afzonderlijke vergunningen benodigd waren voor de inzameling en verwerking daarvan. Dit is nu niet meer het geval, maar de ACM laat verder in het midden hoe de productmarkt gedefinieerd dient te worden. Als er verder wordt gekeken naar de markt voor de inzameling van afval van raffinaderijen en chemisch afval, dan heeft Van Gansewinkel een marktaandeel van 30-40 procent. Echter, als men kijkt naar de bredere markt van inzameling van onverpakt (bulk) gevaarlijk afval, dan hebben partijen gezamenlijk erg lage marktaandelen. Bovendien zijn de klanten grote, professionele partijen die over voldoende inkoopkracht beschikken.

Voor de recycling van onverpakt (bulk) gevaarlijk afval makt ACM wel nader onderscheid en heeft zij eerder besloten dat het recyclen van ows-mengsels (een mengsel van vervuild water met olie en slib) een afzonderlijke productmarkt vormt. De ACM laat echter ook bij deze markt in het midden of er sprake is van één markt voor de recycling van onverpakt (bulk) gevaarlijk afval of dat er verder onderscheid moet worden gemaakt. Ook al is een exportvergunning nodig voor het verwerken van dit afval in het buitenland, dit is wel een reële optie. Hoewel de ACM eerder de markt als nationaal heeft afgebakend, zijn er nu dus aanwijzingen dat de geografische markt wellicht breder kan zijn. De ACM laat echter ook de geografische afbakening in het midden.

Shanks is de enige partij in Nederland die ows-mengsels kan scheiden én afvalstromen na de scheiding volledig kan verwerken en samen met Van Gansewinkel heeft Shanks een marktaandeel van 40-50 procent. Er bestaat zowel een horizontale als verticale relatie tussen de activiteiten van Shanks en Van Gansewinkel. De ACM heeft dus ook gekeken naar de mogelijke mededingingsverstorende effecten door de verticale relatie, zowel voor de markt voor recycling van verpakt (klein) als onverpakt (bulk) gevaarlijk afval. Een concurrent van partijen, Suez, stelt dat Shanks op de Nederlandse markt van zowel recyling van specifiek verpakt (klein) gevaarlijk afval als de markt van specifieke ows-mengsels een marktaandeel van 90-100 procent heeft. Echter, de ACM concludeert dat voor deze specifieke markten een uitsluitingsstrategie niet mogelijk is, omdat Shanks afhankelijk blijft van derden om de volledige capaciteit van de installatie te vullen en daarmee winstgevend te kunnen laten zijn. Bovendien zijn er genoeg (buitenlandse) alternatieven. Voor het overig verpakt (klein) en onverpakt (bulk) gevaarlijk afval zijn er ook voldoende financieel aantrekkelijke alternatieven, waardoor de ACM concludeert dat partijen geen economische prikkel zullen hebben om Shanks' capaciteit te vullen met afval van Van Gansewinkel.

Hoewel het gaat om een fusie tussen twee van de drie grootste spelers op de bredere markt van afvalinzameling en -verwerking komt de ACM tot de conclusie dat de fusie niet zal leiden tot mededingingsproblemen op de te onderscheiden markten. Dat heeft in de eerste plaats te maken met het feit dat partijen in specifieke segmenten minder met elkaar concurreren dan op het eerste gezicht lijkt. Ten tweede kent de ACM veel 
gewicht toe aan de meningen van afnemers, die verklaarden niet te verwachten dat partijen door de fusie in staat zouden zijn om winstgevend de prijzen te verhogen en/of de kwaliteit te verlagen. De ACM concludeert daarom dat er voor de concentratie geen vergunning vereist is.

\section{Sligro/Heineken}

Op 12 september 2017 heeft de ACM de overname door Sligro van een deel van de groothandelsactiviteiten van Heineken goedgekeurd. ${ }^{8}$ Deze activiteiten bestaan uit de groothandelsactiviteiten voor foodproducten en hieraan gerelateerde non-foodproducten van Heineken, met uitzondering van de groothandelsactiviteiten voor bier en cider. De concentratie maakt deel uit van een bredere samenwerking tussen Sligro en Heineken. Naast deze overname bestaat die samenwerking uit het sluiten van een aantal overeenkomsten voor logistieke dienstverlening door Sligro voor de bier- en ciderportfolio van Heineken. Verder is Heineken van plan de groothandelsactiviteiten voor bier- en ciderproducten van Sligro over te nemen. De ACM moet daarom eerst de vraag beantwoorden of deze elementen ook deel uitmaken van de voorgenomen concentratie. De ACM stelt ten eerste vast dat deze twee aansluitende plannen op zichzelf geen concentraties zijn. De te sluiten overeenkomsten leiden niet tot een wijziging van zeggenschap. De overname van de groothandelsactiviteiten voor bier- en ciderproducten van Sligro haalt de meldingsdrempels niet. Uit de interne stukken van partijen leidt de ACM af dat er een sterke verwantschap bestaat tussen de verschillende plannen van partijen. De ACM laat echter in het midden of die plannen een rechtstreeks en onmiddellijk gevolg zijn van de voorgenomen concentratie of dat deze als onderdeel van de counterfactual gezien moeten worden, omdat dat voor de beoordeling niet uit zou maken. Net als in eerdere besluiten gaat de ACM bij de marktafbakening uit van afzonderlijke markten voor de groothandel voor binnenhuiselijke consumptie (retail) en buitenhuiselijke consumptie (out-of-home). Er is alleen overlap op de buitenhuiselijke markt. De ACM ziet geen redenen om nader onderscheid te maken binnen deze markt naar het type groothandel, type afnemer en type product dat de groothandels aanbieden. Net als in eerdere besluiten gaat de ACM uit van nationale markten.

Uit het marktonderzoek van de ACM komen geen zorgen van derden naar voren over de overname van de groothandelsactiviteiten. Wel klagen concurrenten en afnemers over de te sluiten overeenkomsten tussen Sligro en Heineken, met name over de afspraak dat Sligro het exclusieve recht krijgt om Heineken-fusten te leveren. Sligro kan volgens haar concurrenten door de overeenkomsten de klanten van Heineken een totaallevering aanbieden, wat die klanten ertoe zal zetten om voor de inkoop van food- en gerelateerde non-foodproducten naar Sligro over te stappen. Ook zou Sligro hierdoor grote schaalvoordelen kunnen behalen. Vooral voor klei- nere afnemers zou het na de voorgenomen concentratie aantrekkelijk worden om over te stappen op Sligro.

De ACM ziet evenwel geen mededingingsproblemen. Wat de overname van de groothandelsactiviteiten van Heineken betreft, stelt de ACM dat het marktaandeel van Sligro na de voorgenomen concentratie op de markt voor groothandel van food- en gerelateerde non-foodproducten voor buitenhuiselijke consumptie minder dan 30 procent zal bedragen. Voor de beoordeling van de effecten van de tussen partijen te sluiten overeenkomsten kijkt de ACM allereerst naar een 'Upsell Model' dat Sligro heeft opgesteld. Dit model laat zien hoeveel extra verkopen Sligro verwacht te realiseren bij klanten van Heineken door de exclusieve samenwerking die zij met Heineken aangaat. Hieruit blijkt dat het marktaandeel van Sligro op de groothandelsmarkt, als deze extra verkopen in aanmerking worden genomen, nog altijd niet boven de 30 procent zal uitkomen. Het model rekent echter met een gemiddelde inkoopwaarde per horecaklant die in de praktijk mogelijk hoger kan liggen. De ACM gaat daarom zelf rekenen op basis van een gemiddelde inkoop van 80.000 euro per horeca-afnemer. Ook dan is het resultaat relatief beperkt. In het scenario waarin ervan wordt uitgegaan dat Sligro de totale groothandelsverkoop voor alle 18.000 Heineken-klanten over zou nemen en de gemiddelde inkoop op 80.000 euro zou liggen, zou het marktaandeel van Sligro na de concentratie tussen 30-40 procent liggen. Dit scenario acht de ACM echter onwaarschijnlijk. Opvallend is dat de ACM in de conclusie van het besluit stelt dat deze marktaandelen niet zo hoog zijn dat Sligro als gevolg van de voorgenomen concentratie een dominante positie verkrijgt, terwijl dat niet de toets is. In ieder geval ondervindt Sligro verder voldoende concurrentiedruk van zowel andere groothandels als van directe leveringen door fabrikanten en inkoop bij supermarkten. Bovendien is het voor afnemers relatief eenvoudig om te wisselen van leverancier.

De ACM acht het niet aannemelijk dat de voorgenomen concentratie zal leiden tot een significante belemmering van de mededinging en keurt de transactie goed.

\section{Talpa/Sanoma}

Op 10 juli 2017 heeft de ACM bepaald dat geen vergunning is vereist voor de overname van Sanoma Image B.V. (hierna: Sanoma) door Talpa Holding N.V. (hierna: Talpa). ${ }^{9}$ De activiteiten van Talpa en Sanoma overlappen op het gebied van het aanbieden van advertentieruimte op televisie en online. Daarnaast bestaat mogelijk een verticale relatie tussen het produceren van tv-content door Talpa en het exploiteren van televisiezenders door Sanoma. Bij een aantal activiteiten is er geen overlap maar zijn de activiteiten voor adverteerders complementair aan elkaar. Talpa houdt voorafgaand aan de fusie al 33,001 procent van de aandelen in Sanoma. Bij die eerdere verkrijging van gemeenschappelijke zeggenschap over Sanoma Image door Talpa zag de ACM 
(toen nog NMa) geen mededingingsproblemen. ${ }^{10} \mathrm{Nu}$ verkrijgt Talpa uitsluitende zeggenschap.

In eerdere besluiten zijn de ACM en de Europese Commissie uitgegaan van aparte markten voor de verkoop van advertentieruimte op de verschillende media televisie, radio, print en online. Partijen betogen dat dit tezamen één markt vormt voor de verkoop van multimediale advertentieruimte, mede gelet op de sterke groei van online advertenties. Hoewel marktonderzoek aanleiding geeft voor een dergelijke ruimere marktafbakening laat de ACM uiteindelijk in het midden of van een ruimere productmarkt moet worden uitgegaan, omdat het voor de beoordeling niet uitmaakt. De ACM gaat uit van nationale markten voor de verkoop van advertenties op televisie, print, radio en internet. De concentratie zal op de markt voor de verkoop van televisieadvertentieruimte leiden tot een kleine toename van het gezamenlijk marktaandeel van partijen. De ACM concludeert daarom dat de concentratie op deze markt niet zal leiden tot een significante belemmering van de mededinging. Hetzelfde geldt voor de markt voor de verkoop van internetadvertentieruimte in Nederland.

Een mogelijk effect van de voorgenomen fusie kan evenwel zijn dat er door conglomeratie- of portfolio-effecten mededingingsproblemen ontstaan. Deze mogelijkheid is er wanneer Talpa de posities op de radio- en televisieadvertentiemarkt kan combineren. Uit het onderzoek van de ACM blijkt dat de marktpartijen verwachten dat Talpa na de overname de verkoop van de advertentieruimte bij de televisiezenders van Sanoma zal onderbrengen. Hier zou een zogeheten cross-mediaal aanbod van advertentieruimte kunnen ontstaan. Hoewel adverteerders met dit aanbod een ruimere keuze krijgen in advertentiemogelijkheden, kan dit tot mededingingsproblemen leiden wanneer een partij op één of meer markten een sterke positie heeft, die zij zou kunnen overhevelen naar een andere markt en daar concurrenten kan uitsluiten. De ACM stond nu voor de opgave om te beoordelen of (1) de gefuseerde onderneming de mogelijkheid heeft om haar concurrenten uit te sluiten, (2) of zij de economische prikkel heeft om dit te doen en (3) of een dergelijke afschermingsstrategie een aanzienlijke ongunstige invloed op de mededinging heeft.

Talpa heeft een marktaandeel van ongeveer $30-40$ procent op de markt voor de verkoop van radioadvertentieruimte. Talpa verkoopt de radioadvertentieruimte op haar zenders via saleshuis OMS, dat een sterke positie op de radio-advertentiemarkt heeft. Uit onderzoek van de ACM onder marktpartijen volgt dat de belangrijkste radiozenders voor adverteerders zijn ondergebracht bij OMS, dat voor hen de advertentieverkoop verricht. Als gevolg hiervan is een adverteerder die op de radio wil adverteren min of meer gedwongen om met OMS in zee te gaan. Partijen hebben aangevoerd dat enkele grote mediabureaus afnemersmacht hebben, en dat er disciplinerende werking uitgaat van de toenemende concurrentiedruk van online adverteren. De ACM brengt hier echter tegenin dat de sterke positie van OMS op de markt voor de verkoop van radioadvertentieruimte met zich brengt dat Talpa die positie kan inzetten in onderhandelingen met adverteerders om zo haar eigen positie op andere advertentiemarkten te verbeteren.

Dit kan ten eerste onder andere door de sterke positie op de markt voor radioadvertentieruimte over te hevelen naar de markt voor televisieadvertentieruimte, of andersom. Hierdoor kunnen concurrenten op televisieof radiogebied worden uitgesloten. Dit acht de ACM niet waarschijnlijk, omdat het marktaandeel van Sanoma niet zodanig groot is en Talpa nooit de volledige doelgroep kan bereiken. Dit komt doordat ze maar een beperkt aantal zenders heeft en andere marktpartijen als NPO en RTL een groot bereik hebben. Andersom beschikt Sanoma niet over een sterke positie op de markt voor televisieadvertentieruimte en zal zij deze positie dus niet kunnen overhevelen. De ACM ziet deze tweede mogelijkheid voor het verbeteren van de positie van Talpa door middel van een bundelingsstrategie ook niet als een reële optie. De derde verbeteringsmogelijkheid is dat Talpa haar sterke positie op de markt voor de verkoop van radioadvertentieruimte nog verder kan versterken. Talpa zou huidige adverteerders op SBS-televisie (onderdeel van Talpa) korting kunnen geven op hun bestedingen als ze ook op Talpa Radio/OMS adverteren. Op langere termijn zou Talpa adverteerders kunnen uitbuiten door het verhogen van de tarieven. De ACM vindt ook dit scenario niet aannemelijk. Ten eerste is het aanbod van radioadvertentieruimte niet ongelimiteerd en mogen radiozenders maximaal 12 minuten per uur besteden aan reclame. Daarnaast is Talpa niet volledig eigenaar van OMS en Talpa Radio en komen de kosten voor het aanbieden van korting volledig bij Talpa, terwijl de winst eruit gedeeld wordt met de medeeigenaren van OMS en Talpa Radio. Ten derde brengt korting geven op televisieadvertentieruimte een risico met zich dat er televisieomzet verloren gaat in de hoop op meer omzet uit radioadvertenties.

De ACM heeft vervolgens onderzoek gedaan naar adverteerders die mogelijk in ruil voor een korting van 10 procent over zouden stappen naar concurrerende radiozenders van Talpa Radio. Uit het onderzoek blijkt dat het voor de meeste adverteerders niet aantrekkelijk is om veel radiobudget te verschuiven naar Talpa. In het porstcasescenario is de ACM ervan uitgegaan dat adverteerders 25-35 procent van hun radiobestedingen naar OMS moeten verschuiven, en het gevolg hiervan zou zijn dat de effectiviteit van de radiocampagne zeer significant afneemt. Hoewel Talpa mogelijkerwijs crossmediaal aanbod van advertentieruimte kan bieden, concludeert de ACM dat dit niet zal leiden tot mededingingsproblemen ontstaan door conglomeratie- of portfolio-effecten. De ACM keurt de transactie daarom goed.

\section{Mediahuis/Telegraaf}

Op 1 mei 2017 heeft de ACM bepaald dat geen vergunning is vereist voor de overname van Telegraaf Media Groep N.V. door Mediahuis N.V. ${ }^{11}$ De activiteiten van 
Mediahuis en TMG overlappen op het gebied van (1) het uitgeven van betaalde regionale en landelijke dagbladen, (2) het aanbieden van advertentieruimte voor landelijke advertenties in regionale en landelijke dagbladen, (3) het aanbieden van online advertentieruimte en (4) het aanbieden van online ruimte voor personeelsadvertenties. Daarnaast bestaat een verticale relatie tussen het uitgeven van dagbladen door Mediahuis en de activiteiten van TMG op (5) de markt voor distributie van dagbladen en (6) de markt voor het vervaardigen van coldset offset drukwerk (een druktechniek voor het drukken van kranten). Deze laatste twee markten waren niet problematisch. De uitgeverijen Persgroep, TMG en NDC hebben samen, vanwege efficiëntieredenen, een onderverdeling gemaakt van de distributiegebieden. Elke uitgever distribueert enkel in de gebieden waar hij de meeste abonnees heeft. Deze verdeling wijzigt nauwelijks als gevolg van de concentratie. Daarnaast heeft de drukmarkt overcapaciteit en is er volop concurrentie. Partijen zijn beide actief op zowel de markt voor betaalde regionale dagbladen als landelijke dagbladen en stellen dat er in de lezersmarkt voor betaalde regionale en landelijke dagbladen niet of nauwelijks sprake is van concurrentiedruk tussen regionale en landelijke dagbladen. In het eerdere Persgroep/Mecom-besluit heeft de ACM ook geconcludeerd dat zij, hoewel er in die zaak sprake was van gezamenlijke marktaandelen van meer dan 80 procent in bepaalde gebieden, geen reden zag om onderzoek te doen naar de overlap tussen landelijke dagbladen en regionale dagbladen. De ACM heeft in het onderhavige besluit in het midden gelaten of de lezersmarkt voor regionale en landelijke dagbladen nader dient te worden afgebakend en heeft ook in het midden gelaten of de markt moet worden afgebakend op nationaal of enger regionaal niveau.

Op landelijk niveau geeft Mediahuis de landelijke dagbladen NRC Handelsblad en nrc.next uit. TMG geeft het landelijke dagblad De Telegraaf en het gratis dagblad Metro uit. Na de fusie zouden de partijen een gezamenlijk marktaandeel van ongeveer 30-40 procent hebben op de markt voor regionale en landelijke dagbladen, maar de ACM concludeert dat de concentratie niet zal leiden tot belemmeringen van de mededinging. Aan deze conclusie ligt het volgende ten grondslag. De regionale dagbladen worden uitgegeven in verschillende gebieden die niet overlappen, dus concurreren de partijen daar niet met elkaar. Daarnaast stappen lezers van landelijke bladen nauwelijks over en blijkt uit door partijen overlegde onderzoeken dat De Telegraaf aan de ene kant en NRC Handelsblad en nrc.next aan de andere kant in zeer beperkte mate substituten van elkaar zijn. Dat zouden lezers van een van beide kranten ongetwijfeld beamen. Daarnaast volgt uit het onderzoek dat Mediahuis en TMG op deze markten concurrentiedruk ervaren van onder meer (gratis) online nieuwsmedia en online adverteren. De ACM acht het niet aannemelijk dat de Persgroep en Mediahuis hun gedrag gaan coördineren, gelet op de verschillen tussen de door hen uitgegeven dagbladen en de dynamische ontwikkelingen in de mediasector.
Zowel Mediahuis als TMG biedt advertentieruimte an in haar regionale en landelijke dagbladen. De ACM is hierbij uitgegaan van een markt voor landelijke advertenties in regionale en landelijke dagbladen waarbij in het midden kan worden gelaten of een dergelijke markt ook landelijke advertenties in andere (online) media omvat. De ACM gaat uit van een nationale markt. Door deze overname verandert er weinig als bedrijven kiezen voor een krantenadvertentie voor een bepaalde lezersgroep. Volgens de mediabureaus concurreren NRC Handelsblad en nrc.next met de Volkskrant om adverteerders en De Telegraaf met het Algemeen Dagblad. Evenals in het hierboven besproken Talpa/Sanomabesluit speelt ook hier de toenemende concurrentiedruk van de online advertentiemarkt een grote rol - adverteren in dagbladen wordt enkel nog gezien als een aanvulling op online adverteren. Mediahuis, TMG en BDUmedia maken samen gebruik van het samenwerkingsverband Promille Media om aan adverteerders de mogelijkheid te bieden in verschillende regionale dagbladen te adverteren. De ACM acht het niet aannemelijk dat de positie van BDU in dit samenwerkingsverband zou verslechteren als gevolg van de fusie, angezien de deelnemers in Promille Media hun eigen tarieven en voorwaarden voor de advertenties bepalen.

Wat betreft de markt voor online advertenties heeft de ACM in het midden gelaten of deze markt ook landelijke advertenties in dagbladen omvat. In de beoordeling is de ACM uitgegaan van een nationale markt voor online advertenties. Een aanzienlijk deel van het budget voor online advertenties gaat naar Google en Facebook. De ACM concludeert daarom dat er als gevolg van de concentratie geen mededingingsproblemen op de markt van online advertenties zullen optreden. De Europese Commissie heeft in eerdere beschikkingen overwogen dat er een aparte productmarkt bestaat voor online personeelsadvertenties en de ACM sluit hierbij aan. De ACM laat hierbij in het midden of de markt mogelijk een ruimere omvang dan nationaal heeft. Zowel Mediahuis als TMG heeft een aantal online personeelsadvertentiewebsites. Mogelijkerwijs kunnen portfolio-effecten optreden als gevolg van de concentratie. Evenals in het Talpa/Sano$m a$-besluit hierboven concludeert de ACM echter dat het aanbieden van advertentieruimte op verschillende media eerder leidt tot ruimere keuze voor adverteerders en enkel leidt tot mededingingsproblemen indien een partij haar sterke positie op de ene markt kan overhevelen naar een andere markt. De ACM acht het echter niet aannemelijk dat Mediahuis een zodanig sterke positie zal verkrijgen door de fusie.

Gelet op het voorgaande heeft de ACM geen reden om aan te nemen dat deze concentratie de daadwerkelijke mededinging op de Nederlandse markt of een deel daarvan op significante wijze zou kunnen belemmeren. 


\section{Vergunningsfase}

De ACM heeft in 2017 twee concentraties in de vergunningsfase beoordeeld. Dat was de overname van Antes door Parnassia en de fusie van het AMC en het VUmc.

\section{Parnassia/Antes}

Op 12 juni 2017 keurde ACM onder voorwaarden de overname van Parnassia door Antes goed..$^{12}$ Het eerstefasebesluit in deze zaak is reeds in de kroniek van 2015 besproken. ${ }^{13}$ In dat besluit oordeelde de ACM dat het aannemelijk was dat de concentratie zou leiden tot een significante belemmering van de mededinging op de markt voor specialistische geestelijke gezondheidszorg (hierna: sGGZ). In het vergunningsbesluit is de overname onder voorwaarden goedgekeurd. Dit besluit bevat een uitgebreide analyse van de markt, zowel wat betreft de marktafbakening als de gevolgen van de concentratie. Parnassia en Antes zijn beide actief als algemene en forensische GGZ-aanbieder in Rotterdam en de regio eromheen. De ACM concludeert in dit besluit dat de gemelde concentratie niet zal leiden tot een significante verstoring van de mededinging op de markten voor verslavingszorg en woonbegeleiding. De concentratie zal de mededinging daarentegen wél significant verstoren op de markten voor klinische en ambulante sGGZ voor volwassenen en ouderen (hierna: $\mathrm{V} \& \mathrm{O}$ ) in de regio Rotterdam-Rijnmond.

De concentratie leidt allereerst tot zeer hoge gezamenlijke marktaandelen op de markt voor klinische en ambulante sGGZ voor $\mathrm{V} \& \mathrm{O}$ in de stad Rotterdam en de regio Rotterdam-Rijnmond. Volgens partijen moet er binnen de sGGZ naast de klinische en ambulante markten tevens een aparte markt afgebakend worden voor de zorg voor patiënten met Ernstige Psychiatrische Aandoeningen (hierna: EPA). Ze voeren aan dat EPA-patienten doorgaans geen hulpvraag hebben en zorgmijdend zijn, en dus geen keuze maken voor een bepaalde zorgaanbieder. Het onderzoek in deze zaak duidt echter aan dat de sGGZ niet verder moet worden gesegmenteerd in complexheid van de aandoeningen, zoals EPA, omdat de verschillende patiënten geen wezenlijk andere keuzes maken voor hun zorgaanbieder. Daarnaast stellen partijen dat de klinische sGGZ gefinancierd uit de Wet langdurige zorg (Wlz) eveneens een apart te onderscheiden markt is, omdat het geen economische activiteit zou zijn. De ACM brengt hiertegenin dat de zorg na invoering van de Wlz inhoudelijk hetzelfde is gebleven en dat de wijzigingen met de invoering enkel zagen op een nieuw financieringssysteem. Tot slot stellen partijen dat de markt voor klinische sGGZ gefinancierd uit de Zorgverzekeringswet in zijn geheel zal verdwijnen. Als gevolg van een sterkere nadruk op ambulante zorg vindt een beddenreductie plaats. Daarom zijn partijen van mening dat de klinische capaciteit in de toekomst alleen nog zal bestaan uit gedwongen opnames en betogen dat de

12. Besluit ACM 12 juni 2017, zaak 15.1259.24 (Parnassia/Antes).

13. Zie Kroniek Concentratiecontrole 2015 en besluit ACM 6 november 2015, zaak 15.0992.22 (Parnassia/Antes). markt dus in zijn geheel zal verdwijnen. De ACM vindt het op grond van onderzoek onder zorgverzekeraars aannemelijk dat de markt zal krimpen, maar het staat niet voldoende vast dat de markt in zijn geheel zal verdwijnen. De ACM gaat uit van een beddenreductie van 33 procent, wat slechts zorgt voor een kleine verandering in marktaandeel. Uit herkomstgegevens van partijen blijkt dat de markten voor zorg op het gebied van klinische en ambulante sGGZ regionaal zijn. De relevante regio wordt afgebakend als de regio Rotterdam-Rijnmond.

De ACM kijkt in de inhoudelijke beoordeling eerst naar de markt voor klinische sGGZ voor V\&O. Parnassia en Antes zijn de enige twee grote geïntegreerde GGZ-aanbieders in de regio Rotterdam-Rijnmond en hun gezamenlijke marktaandeel op deze markt is circa $70-80$ procent. Er zijn slechts drie andere zorgaanbieders actief op de markt voor klinische sGGZ voor $\mathrm{V} \& \mathrm{O}$, namelijk Yulius, EMC en GGZ Delfland. Hierbij moet worden opgemerkt dat het zorgaanbod van Yulius en EMC grotendeels afwijkt van dat van partijen en nauwelijks inwisselbaar is. Zij zijn dus beide geen nabije concurrent. GGZ Delfland is vanuit geografisch oogpunt een minder nabije concurrent omdat zij zich niet primair richt op de regio Rotterdam-Rijnmond en geen klinische faciliteiten in Rotterdam heeft. De NZa heeft een analyse gemaakt van uitstroomcijfers en deze analyse laat zien dat in de regio Rotterdam-Rijnmond partijen elkaars meest belangriike alternatieven zijn op het gebied van klinische sGGZ. De concurrentie van andere spelers op deze markt is te beperkt om partijen na de voorgenomen concentratie te kunnen disciplineren.

Op de regionale markt voor ambulante sGGZ voor $\mathrm{V} \& \mathrm{O}$ is het gezamenlijke marktaandeel van partijen zelfs nog hoger, circa $80-90$ procent. De concurrentie is zeer versnipperd en veel marktspelers bieden doorgaans minder complexe ambulante sGGZ aan dan Parnassia en Antes. De concurrentiedruk van deze spelers is dan ook onvoldoende. Ook hier bevestigt de uitstroomanalyse van de NZa dat partijen elkaars meest nabije concurrenten zijn. De partijen hebben onderzoek laten doen door Lexonomics naar afnemersmacht. Lexonomics concludeert dat, omdat zorgverzekeraars in staat zijn om de tarieven onder het maximumtarief uit te onderhandelen, zij de bovenliggende partij zijn en over een sterke onderhandelingspositie beschikken. De ACM brengt hier echter tegenin dat dit alleen geldt in een situatie waarin er meerdere zorgaanbieders zijn. $\mathrm{Na}$ de fusie blijft alleen Parnassia als enige grote GGZ-instelling in de regio Rotterdam-Rijnmond over. Parnassia en Antes hebben toezeggingen gedaan aan de zorgverzekeraars, waarna de verzekeraars zich positief hebben uitgelaten over de voorgenomen fusie. In het meldingsbesluit hield de $\mathrm{ACM}$ al geen rekening met deze toezeggingen, omdat ze de toezeggingen niet zagen als een marktomstandigheid maar als commerciële afspraken. Op basis van gesprekken met zorgverzekeraars concludeert de ACM dat zorgverzekeraars zich eerder positief hebben uitgelaten over de fusie, maar dit deden op basis van andere, meer strategische, belangen. De ACM beschouwt de toezeg- 
gingen dus niet als een marktomstandigheid waaruit compenserende afnemersmacht blijkt.

De eventuele inzet van instrumenten zoals selectieve inkoop of overheveling van budget biedt voor zorgverzekeraars betere mogelijkheden om partijen effectief te disciplineren, maar de zorgverzekeraars kunnen deze instrumenten beperkt inzetten omdat er geen alternatief in de regio meer is. Gelet op de zorgplicht van zorgverzekeraars om Parnassia als grootste aanbieder te contracteren, de bestaande wederzijdse afhankelijkheid tussen partijen en individuele zorgverzekeraars en de vergelijkbare marktposities van individuele zorgverzekeraars in deze regio, acht de ACM het niet aannemelijk dat zorgverzekeraars beschikken over compenserende afnemersmacht.

Hoewel er niet veel benodigde investeringen zijn voor het toetreden tot de markt voor ambulante sGGZ, blijkt uit marktonderzoek dat toetreding alleen kan plaatsvinden als zorgverzekeraars hiermee akkoord gaan en dat het lastig is om als toetreder een contract met een zorgverzekeraar af te sluiten omdat zorgverzekeraars momenteel terughoudend zijn met het overhevelen van budget. Hierdoor is het volgens de ACM aannemelijk dat er op zowel de markt voor klinische sGGZ voor $\mathrm{V} \& \mathrm{O}$ als op de markt voor ambulante sGGZ voor $\mathrm{V} \& \mathrm{O}$ in de regio Rotterdam-Rijnmond onvoldoende concurrentiedruk uitgaat van toetreding dan wel uitbreiding.

In het kader van de zorgspecifieke fusietoets heeft de NZa voor de cruciale zorg die Parnassia en Antes aanbieden (te weten crisisopvang GGZ), onderzocht of patiënten door het samengaan niet verder hoeven te reizen of langer hoeven te wachten dan wat volgens de wet maximaal acceptabel is. Uit het onderzoek van de NZa blijkt dat de continuiteit van deze zorg niet in gevaar komt. De NZa neemt in haar zienswijze de bevindingen op van de IGZ, die heeft aangegeven dat op basis van de informatie die voorhanden is, geen uitspraak gedaan kan worden over hoe de kwaliteit en veiligheid van de zorg zich na de voorgenomen concentratie zullen gaan ontwikkelen.

Parnassia en Antes hadden al in de meldingsfase een efficiëntieverweer gevoerd, maar de ACM heeft pas in de vergunningsfase naar dit verweer gekeken in verband met de complexiteit ervan. Partijen stellen dat de voorgenomen concentratie efficiëntievoordelen met zich brengt die opwegen tegen eventuele mededingingsrechtelijke nadelen, bestaande uit kostenvoordelen en zorginhoudelijke voordelen. De ACM is niet overtuigd door dit efficiëntieverweer. In de eerste plaats acht de ACM het niet aannemelijk dat de positie van de zorgverzekeraars voldoende sterk is dat de eventuele kostenvoordelen worden doorgegeven aan verzekerden. De kostenvoordelen zijn niet volledig onderbouwd, waardoor het niet duidelijk is gemaakt dat de kostenvoordelen specifiek het resultaat zijn van de voorgenomen fusie. Daarnaast is de ACM van mening dat een groot deel van de aangevoerde voordelen niet verifieerbaar is. Het is bovendien niet duidelijk welke prikkel de partijen hebben om de aangevoerde voordelen te realiseren. Vervolgens is het ook niet duidelijk of de zorginhoudelijke voordelen zouden optreden. Parnassia en Antes beweren dat de fusie tot gevolg zou hebben dat er minder vaak patiënten hoeven te worden overgedragen tussen hen en dat dit de kwaliteit van de zorg ten goede komt. Het marktonderzoek van de ACM laat echter geen eenduidig beeld zien, maar bevestigt dat het moment van overdracht van patiënten tussen behandelaren inderdaad een risicovol moment is. Het is niet duidelijk of dit moment beter zou verlopen als gevolg van de fusie. De ACM concludeert dat het efficiëntieverweer niet voldoende overtuigend is.

De fusie heeft ook gevolgen op de markt voor forensische zorg. De activiteiten van Parnassia en Antes overlappen ook op deze markt in de regio Rotterdam-Rijnmond. In het meldingsbesluit heeft de ACM geen beslissing genomen over de marktafbakening. De ACM komt nu tot de conclusie dat de markt voor forensische verslavingszorg moet worden onderscheiden van de overige forensische zorg. Daarbinnen moet vervolgens een onderscheid worden gemaakt tussen ambulante en klinische forensische zorg. Er zijn vervolgens ook beperkte substitutiemogelijkheden tussen de verschillende beveiligingsniveaus in de klinische forensische zorg. De activiteiten van Parnassia (via een dochteronderneming genaamd Fivoor) en Antes overlappen op de markt voor klinische forensische zorg met beveiligingsniveau één en twee in de regio Rotterdam-Rijnmond. De fusie zou op deze markt leiden tot een monopoliepositie voor de partijen, aangezien ze een gezamenlijk marktaandeel van 100 procent zouden bereiken. De Dienst Justitiële Inrichtingen (hierna: DJI) is de enige inkoper van forensische zorg en beschikt over onvoldoende compenserende afnemersmacht om de positie van partijen na de voorgenomen concentratie te disciplineren. Voor deze markt hebben Parnassia en Antes geen efficiëntieverweer gevoerd.

Om de mededingingsbezwaren die de ACM heeft geconstateerd weg te nemen, hebben partijen een remedievoorstel ingediend dat de ACM heeft geaccepteerd.

Het voorstel houdt in dat bepaalde klinieken, behandelcentra en patiënten van zowel Parnassia als Antes worden afgestoten. Parnassia verbindt zich om zorgactiviteiten ter grootte van 105 open bedden en één ambulante locatie en twee ambulante zorgteams af te stoten en Antes verbindt zich ertoe 20 open bedden en de klinische forensische zorg met beveiligingsniveau één die is ingekocht door DJI af te stoten. Parnassia en Antes hebben aan de ACM toestemming gevraagd voor de verkoop van de klinieken, behandelcentra en patiënten aan GGZ Delfland. ACM heeft deze verkoop op 28 juli 2017 goedgekeurd. GGZ Delfland is nu al actief als aanbieder van GGZ in de regio Rotterdam-Rijnmond en zal door deze afstoting substantieel groter worden. Naast het afstoten van een deel van de activiteiten, eist de ACM dat Parnassia en Antes de afspraken uit het Bestuurlijk akkoord geestelijke gezondheidszorg nakomen. Zij moeten daarom de komende twee jaar krimpen in het aantal 'bedden' en verplichten zich ertoe om per 31 december 2019 hun gezamenlijk aantal open bedden op de markt voor klinische sGGZ voor V\&O in de regio 
Rotterdam-Rijnmond afgebouwd te hebben tot twee derde van het totaal aantal open bedden in 2008. Op die manier rust voor GGZ Delfland geen afbouwverplichting op de 125 open bedden die zij van Parnassia en Antes overneemt.

Deze voorschriften nemen de geconstateerde mededingingsproblemen weg. De ACM heeft een markttest uitgevoerd, waaruit blijkt dat alle partijen de beoogd koper geschikt vinden. Op de markten waar Parnassia na de voorgenomen concentratie een zeer sterke positie zou verkrijgen, wordt deze positie door het remedievoorstel beperkt, en wordt de afhankelijkheid van Parnassia voor zorgverzekeraars gecompenseerd. Als gevolg van de voorschriften ontstaat voor zorgverzekeraars een reëel alternatief voor Parnassia/Antes in de regio RotterdamRijnmond. Omdat de voorschriften alle geconstateerde mededingingsproblemen wegnemen, heeft de ACM het remedievoorstel geaccepteerd en verleent de ACM de vergunning onder voorwaarden.

\section{AMC/VUmc}

Op 5 september 2017 heeft de ACM een vergunning verleend voor de fusie tussen het Academisch Medisch Centrum (hierna: AMC) en Stichting VUmc (hierna: VUmc) in Amsterdam. ${ }^{14}$ In het meldingsbesluit, ${ }^{15}$ dat de ACM eind 2016 heeft genomen, concludeerde de ACM dat de voorgenomen fusie de daadwerkelijke mededinging op de markt voor topzorg op significante wijze zou kunnen belemmeren. Onderzoek in de vergunningsfase heeft uitgewezen dat die zorgen er niet zijn.

In de meldingsfase worstelde de ACM met de marktafbakening omdat de productmarkten waarop partijen actief zijn moeilijk zijn af te bakenen. Uiteindelijk kwam de ACM, grotendeels in lijn met eerdere besluiten, tot een grove onderverdeling in basiszorg en topzorg. In het vergunningsbesluit gaat het specifiek om de markt voor topzorg. Dat is zorg die dusdanig complex is dat patiënten hiervoor niet naar een basisziekenhuis kunnen en die over het algemeen alleen in STZ-ziekenhuizen ${ }^{16}$ of UMC's wordt aangeboden. Voor bepaalde topzorg concurreren UMC's zelfs alleen onderling of helemaal niet. Dat is bijvoorbeeld het geval bij zeer gespecialiseerde zorg die verband houdt met unieke expertise en wetenschappelijke speerpunten rondom zeldzame ziekten. De ACM noemt dit 'niet-concurrentiële topzorg'. Deze marktafbakening is bevestigd door het onderzoek van de ACM in de vergunningsfase. Bij de beoordeling van de concentratie kijkt de ACM naar de topzorg waarvoor wel concurrentie is.

In het meldingsbesluit is de ACM op basis van zowel kwalitatief als kwantitatief onderzoek uitgegaan van een geografische markt die bestaat uit de provincie NoordHolland en de gemeenten Lelystad, Almere en De Ronde Venen. Uit al deze gemeenten gaan substantiële stromen van patiënten naar het AMC en het VUmc in Amsterdam. $\mathrm{Nu}$ partijen deze marktafbakening niet betwisten gaat de ACM ook in de vergunningsfase van deze markt uit.

Partijen betogen in feite dat er geen daadwerkelijke concurrentie is op de markt voor topzorg, nu patiënten geen weloverwogen keuzes maken voor ziekenhuizen, en verzekeraars geen topzorg verplaatsen. Verder zouden de activiteiten van partijen maar beperkt overlappen. Zorgverzekeraars en de NZa zijn echter niet onverdeeld positief over de fusie. Hoewel zorgverzekeraars erkennen dat zij zelden topzorg verplaatsen, beschouwen zij dit wel als een 'ultieme optie' die hun onderhandelingspositie versterkt. De zorgverzekeraar die verreweg de meeste zorg inkoopt bij partijen - Zilveren Kruis - geeft dan ook aan dat de onderhandelingspositie tegenover het fusieziekenhuis zal verslechteren en het fusieziekenhuis een partij is die men wel zal moeten contracteren. De NZa vindt dat de fusie een te groot ziekenhuis creëert, wat schadelijk zal zijn voor de kwaliteit en betaalbaarheid van de zorg. De econometrische modellen van de $\mathrm{NZa}$ voorspellen prijsstijgingen tot 15 procent.

De ACM is het niet eens met de opvatting van partijen over het gebrek aan concurrentie, maar concludeert uiteindelijk dat de fusie niet zal leiden tot een significante belemmering van de mededinging. Daar ligt het volgende aan ten grondslag. Ten eerste is het marktaandeel van partijen (30-40 procent) lager dan in de meldingsfase vastgesteld (50-70 procent). Dat is het gevolg van een meer fijnmazige dataset die de ACM in de vergunningsfase heeft gebruikt. Vervolgens kijkt de ACM naar de concurrentiedruk die door andere ziekenhuizen wordt uitgeoefend. De ACM voert een kwantitatieve overlapanalyse uit waaruit blijkt dat de activiteiten van partijen veel overlap vertonen. Met andere ziekenhuizen is er minder overlap. Uit gesprekken met verzekeraars en andere ziekenhuizen zou echter blijken dat die ziekenhuizen wel degelijk een volwaardig alternatief vormen voor het fusieziekenhuis. Dat zou met name gelden voor het OLVG en voor oncologische zorg voor het Antoni van Leeuwenhoekziekenhuis (hierna: AvL). Er is volgens de ACM ook geen verschil in imago tussen een UMC en een ander ziekenhuis dat topzorg aanbiedt. Uit de welbekende uitwijkpercentages van patiënten blijkt verder dat beide alternatieve Amsterdamse ziekenhuizen (OLVG of AvL) als een nabije concurrent voor zowel AMC als VUmc kunnen worden beschouwd voor vrijwel alle productgroepen. Deze ziekenhuizen zien zelf ook geen probleem in het overnemen van capaciteit van partijen. De ACM acht het dus ook niet aannemelijk dat de onderhandelingspositie van bijvoorbeeld Zilveren Kruis zou verslechteren. Zilveren Kruis werpt verder nog op dat partijen na de fusie een nog sterker blok kunnen vormen, omdat men de unieke zorg van het fusieziekenhuis, die de ACM niet-concurrentiële zorg noemt, dan bij één ziekenhuis moet inkopen. De ACM acht het echter niet aannemelijk dat dat invloed heeft op de onderhandelingen nu er toch geen concurrentie is voor die zorg. De ACM verleent daarom de vergunning. 
Dit besluit van de ACM, dat vrij kort is voor een besluit in de vergunningsfase, ${ }^{17}$ bevat een antal opmerkelijke elementen. Ten eerste signaleert de NZa een aantal concrete zorgen als gevolg van deze fusie, die de ACM in de samenvatting van het besluit wegzet als 'niet binnen de reikwijdte van de mededingingstoets'. Dat is vreemd, nu de NZa het niet alleen heeft over onderwerpen als bestuurbaarheid maar ook prijs en kwaliteit, die nu juist de essentie zijn van de mededingingstoets. Sterker nog, de NZa voorspelt specifieke prijsstijgingen. Ten tweede hecht de ACM minder waarde aan de meningen van zorgverzekeraars dan in voorgaande besluiten in de zorgsector. Dat is tot op zekere hoogte prijzenswaardig $\mathrm{nu}$ het concentratietoezicht geen opiniepeiling is en de ACM zo veel mogelijk zelfstandig onderzoek zou moeten doen, zeker in complexere zaken. Vreemd is echter dat de bezwaren van zorgverzekeraars terzijde worden geschoven op basis van marktaandelen (terwijl de ACM zelf toegeeft dat marktafbakening in dit geval erg lastig was) en argumenten over concurrentiedruk van andere ziekenhuizen die op het eerste gezicht niet allemaal even overtuigend zijn. Ten derde poneert onder andere Zilveren Kruis een interessante benadelingstheorie die wijst in de richting van vermeende conglomeraateffecten. De ACM stelt echter simpelweg dat er geen concurrentie is voor bepaalde typen zorg, zonder te onderzoeken wat de bundeling van die zorg voor gevolgen zou kunnen hebben voor de kracht van het productaanbod van partijen en daarmee hun onderhandelingspositie.

Dit is een punt dat nadere motivering had verdiend.

\section{Ontheffing standstill}

Op basis van artikel $40 \mathrm{Mw}$ kan de ACM wegens gewichtige redenen ontheffing verlenen van de verplichting van artikel $34 \mathrm{Mw}$ om na de melding van een concentratie een wachtperiode van vier weken in acht te nemen. Deze mogelijkheid is met name relevant bij (dreigende) faillissementen. In 2017 heeft de ACM één ontheffing verleend. Op 29 december 2017 heeft het ons inmiddels welbekende Parnassia de ACM verzocht om ontheffing voor de overname van een deel van de activa van Virenze. De ACM heeft het verzoek op dezelfde dag toegewezen. ${ }^{18}$ Virenze is actief op het gebied van kinden jeugdzorg en is op 18 december 2017 failliet verklaard. De curator van Virenze heeft op 20 december 2017 een bod van Parnassia en MET ggzl op de activa van Virenze geaccepteerd. De curator heeft verklaard dat de zorgverlening nog tot 1 januari 2018 kan worden voortgezet, maar financiële verplichtingen voor de periode daarna niet door de boedel gedragen kunnen worden. De ACM acht het aannemelijk dat er een groot risico bestaat voor de continuïteit van de activiteiten van Virenze als zij de wachtperiode in acht moet nemen, maar sluit niet uit dat een vergunning vereist is voor de

17. Slechts 37 pagina's, waarvan 12 pagina's bestaan uit een bijlage.

18. Besluit ACM 29 december 2017, zaak 17.0248.98 (Parnassia Groep/ Virenze). concentratie. De ACM verleent de ontheffing daarom met de voorwaarde dat Parnassia na de concentratie bij de organisatorische of operationele integratie van Virenze niet verder gaat dan noodzakelijk is voor het garanderen van de continuiteit van de zorg voor de overgenomen cliënten, totdat de ACM de concentratie heeft kunnen beoordelen.

\section{Overig}

\section{ACM-rapport - Prijs- en volume-effecten van} ziekenhuisfusies 2007-2014

De ACM heeft in 2017 een rapport gepubliceerd over de prijs- en volume-effecten van ziekenhuisfusies nadat deze hebben plaatsgevonden. Dit rapport heeft aardig wat stof doen opwaaien. De ACM signaleert dat zij de laatste jaren meer mededingingsrisico's bij ziekenhuisfusies ziet, mede door de risico's die zorgverzekeraars zien. In deze studie heeft de ACM prijs- en volumeeffecten van 12 ziekenhuisfusies onderzocht op basis van declaratiegegevens van 62 van de 65 door de NZa gedefinieerde medisch inhoudelijk patiëntgroepen (meer dan 99 procent van de ziekenhuisomzet bij patiëntgroepen). Het onderzoek heeft betrekking op de periode 2007-2014. Dit onderzoek is een tweeluik met een in 2016 gepubliceerd onderzoek naar de kwaliteitseffecten van ziekenhuisfusies (Significant, 2016). De belangrijkste conclusie van dat onderzoek was dat er 'geen indicatie is van een sterk effect van ziekenhuisfusies op de kwaliteit van zorg'. Dit past bij de conclusies uit het literatuuronderzoek, waaruit blijkt dat er geen sterk empirisch bewijs is voor de claim dat een fusie zal bijdragen aan de kwaliteit van zorg.

In dit onderzoek maakt de ACM gebruik van de 'Difference-in-Differences methode': een methode die ervan uitgaat dat prijs- en volumeveranderingen in de controlegroep een goede indicator zijn voor de prijs- en volumeontwikkelingen in de interventiegroep, als de interventie niet zou zijn opgetreden. Het gaat ervan uit dat de ziekenhuizen in de fusiegroep en de controlegroep een parallelle trend in prijs- en volumeontwikkeling doormaken voorafgaand aan de fusies. De belangrijkste conclusie van dit onderzoek is dat er een indicatie is gevonden voor een prijsstijging van de zorg van gefuseerde ziekenhuizen ten opzichte van de prijs van zorg van niet-gefuseerde ziekenhuizen. Daarnaast kan geconcludeerd worden dat het volume zich nauwelijks afwijkend heeft ontwikkeld ten opzichte van niet-gefuseerde ziekenhuizen. Dit blijkt uit Difference-in-Differences regressies van 62 medisch inhoudelijke patiëntgroepen met als afhankelijke variabelen prijs en volume.

$\mathrm{Er}$ is daarnaast gekeken naar de effecten per jaar. De sterkte van de effecten van de Nederlandse ziekenhuisfusies verschilt zowel in tijd als per fusie. Het kan zijn dat de fusie alleen een tijdelijke prijsschok tot gevolg heeft. Na het eerste jaar na de goedkeuring van de fusies is er namelijk al een indicatie dat de prijsstijgingen afzwakken. In het derde jaar na de goedkeuring van de 
fusie zijn er echter in de meeste patiëntgroepen nog prijsstijgingen te zien. De ACM heeft ook gekeken naar individuele fusies, maar er zijn op het niveau van de specifieke fusie weinig statistisch significante effecten.

Zoals gezegd heeft de ACM niet alleen gekeken naar prijs, maar ook naar volume. Er zijn in dit onderzoek maar zeer beperkte indicaties dat het volume van gefuseerde ziekenhuizen zich systematisch anders ontwikkelt dan het volume van niet gefuseerde ziekenhuizen. Als de fusie leidt tot een hogere prijs, zou dit een negatief effect kunnen hebben op het volume, omdat patiënten vanwege de hogere prijs afzien van een behandeling. Echter, aangezien de meeste behandelingen vergoed worden door een zorgverzekeraar, heeft een mogelijk prijsverschil geen effect. Een toename van de relatieve onderhandelingsmacht van het fusieziekenhuis zou ervoor kunnen zorgen dat er een hoger volume wordt uitonderhandeld met de verzekeraar. Uit het onderzoek blijkt echter geen eenduidig effect van fusies op volumeontwikkelingen. De effecten lopen uiteen van een volumedaling van zo'n 12 procent tot een volumestijging van meer dan 25 procent. Op fusieniveau is er bij vijf fusies een omzetstijging. De overige zeven fusies laten een omzetdaling zien. Een hogere HerfindahlHirschman Index (HHI) van een ziekenhuis gaat vaak samen met een relatief hogere prijs. Verder is het interessant om op te merken dat bij de fusie die is goedgekeurd met een remedie, Walcheren-Oosterschelde, sprake is van een relatieve prijsdaling; de remedie heeft mogelijk effect gehad.

Er moet bij dit onderzoek wel worden opgemerkt dat veel coëfficiënten statistisch niet significant zijn en er geen informatie is over de kosten en kostenontwikkeling na de fusie.

Uit eerder onderzoek gecombineerd met dit onderzoek blijkt dat de relatief hogere prijs niet samen gaat met een aantoonbare verbetering van de kwaliteit. De eerdere studie van Significant (2016) laat zien dat wachttijden vaak verslechteren als gevolg van fusies. De ACM geeft aan dat er op basis van deze onderzoeken geen definitief oordeel te geven is of het toezicht op de fusie adequaat is geweest. Gemiddeld genomen zorgden de ziekenhuisfusies echter voor een prijsstijging, zonder dat daar een aantoonbare verbetering in kwaliteit tegenover stond. Dat is opvallend nu de heersende leer van de ACM lange tijd is geweest dat ziekenhuisfusies in beginsel tot efficiëntere en betere zorgverlening zouden moeten leiden, vooral voor meer complexe zorgvragen.

Dit onderzoek bevestigt dat de ACM in de beginjaren van de fusiegolf in de ziekenhuissector te optimistisch is geweest over ziekenhuisfusies en zich te veel heeft laten leiden door de positieve meningen van zorgverzekeraars, die allerlei andere redenen hadden om zich niet tegen fusies te verzetten. Het is goed dat de ACM dit nu heeft onderzocht, maar de vraag blijft waarom zij signalen uit de markt niet eerder heeft opgepakt. Daarnaast is het opmerkelijk dat de ACM drie maanden voor het verschijnen van dit onderzoeksrapport de grote fusie tussen het AMC en VUmc heeft goedgekeurd, terwijl de NZa had voorspeld dat die fusie zou leiden tot prijsstijgin- gen. Bij de beoordeling van die fusie lijkt de ACM minder kritisch te zijn geweest dan in dit rapport en heeft de ACM ook concrete zorgen van verzekeraars terzijde schoven (zie hierboven).

\section{Conclusie}

De verlaagde meldingsdrempels in de zorg blijven hun uitwerking hebben op het concentratietoezicht en ook 2017 was weer een jaar gedomineerd door zorgfusies, hoewel er in tegenstelling tot voorgaande jaren meer inhoudelijke besluiten zijn genomen die zien op andere sectoren. Een opvallende verschijning is het hierboven besproken rapport van de ACM over de gevolgen van ziekenhuisfusies, waaruit blijkt dat die vooral tot prijsstijgingen hebben geleid. Verschillende actoren riepen dit al jaren, maar de ACM kreeg pas oog voor de negatieve kant van ziekenhuisfusies toen zorgverzekeraars bijdraaiden en aangaven dat die fusies toch niet zo positief waren als zij altijd hadden gedacht. Met die kanteling kwamen ook de eerste remedies en verboden fusies. De ACM is zeker een stuk kritischer dan voorheen. In het jaar dat dit rapport verschijnt, keurt de ACM echter ook de grootste ziekenhuisfusie in Nederland ooit goed, terwijl zorgverzekeraars en de NZa niet onverdeeld positief zijn. Een consistente lijn is moeilijk te ontdekken. De indruk ontstaat dat de ACM nog altijd worstelt met het concentratietoezicht in de zorg en geen eenduidige standaard heeft weten te ontwikkelen voor complexe fusies. 